\title{
Reduction in the spray drift of 2,4-D in tomato using hydraulic nozzles with air induction and LI-700 adjuvant ${ }^{1}$
}

\author{
João de Deus Godinho Júnior ${ }^{2}$, Renato Adriane Alves Ruas², \\ Marcelo Rodrigues dos Reis ${ }^{2}$, Alberto Carvalho Filho ${ }^{2}$, Vinícius Ribeiro Faria ${ }^{2}$
}

\section{ABSTRACT}

The drift of hormonal effect herbicides is a major problem for agriculture, because, even in small amounts, it may cause high losses in crops with plants that are sensitive to their action mechanism. This study aimed to evaluate the efficiency of hydraulic spray nozzles with air induction, as well as the use of the LI-700 adjuvant, in the reduction of the 2,4-D herbicide drift, in tomato crop. A complete randomized split-plot experimental design, with eight replications, was used. Two herbicide solutions were assigned in the plots (with or without the use of adjuvant) [2,4-D (670 $\left.\mathrm{g} \mathrm{ha}^{-1}\right)$ and 2,4-D $\left.\left(670 \mathrm{~g} \mathrm{ha}^{-1}\right)+\mathrm{LI}-700\left(712.88 \mathrm{~g} \mathrm{ha}^{-1}\right)\right]$, and, in the subplots, five nozzle models [simple fan (JSF11003), simple fan with air induction (AD-IA11003), dual fan with air induction (AD-IA/ D11003), simple hammer fan with air induction (TTI11003-VP) and empty cone with air induction (CV-IA10003). The treatments were applied in a wind tunnel, under a pressure of $300 \mathrm{kPa}$. In a laser analyzer, applying only water, the volumetric median diameter, the relative amplitude and the percentage of drops with diameter lower than $150 \mu \mathrm{m}$ were measured for all nozzle models. The CV-IA10003 and TTI11003-VP hydraulic nozzles outstand by reducing the 2,4-D herbicide drift and decreasing the damage to tomato plants. The addition of the LI-700 adjuvant to the 2,4-D syrup, independently of the nozzle model, reduces the drift of this herbicide and its effects on the tomato plant root. However, even when adopting these technologies, the application of the 2,4-D herbicide near the tomato crop should be avoided.

KEYWORDS: Solanum lycopersicum; herbicide application technology; spray nozzles.

\section{INTRODUCTION}

The spray drift of pesticides in crops is a major problem for agriculture, and its control is essential to reduce financial and environmental damage, as well as protecting the health of living organisms. The drift of hormonal herbicides, such

\section{RESUMO}

Redução na deriva de pulverização de 2,4-D em tomate utilizando-se pontas hidráulicas com indução de ar e adjuvante LI-700

A deriva de herbicidas de efeito hormonal é um grande problema para a agricultura, pois, mesmo em pequena quantidade, pode causar grandes prejuízos em lavouras com plantas sensíveis ao seu mecanismo de ação. Objetivou-se avaliar a eficiência de pontas hidráulicas de pulverização com indução de ar, bem como o uso do adjuvante LI-700, na redução de deriva do herbicida 2,4-D, na cultura do tomate. $\mathrm{O}$ delineamento experimental utilizado foi o de parcelas subdivididas, inteiramente casualizado, com oito repetições. Nas parcelas, foram alocadas duas soluções do herbicida (com ou sem o uso de adjuvante) [2,4-D (670 $\left.\mathrm{g} \mathrm{ha}^{-1}\right)$ e 2,4-D $\left(670 \mathrm{~g} \mathrm{ha}^{-1}\right)+$ LI-700 $\left.\left(712,88 \mathrm{~g} \mathrm{ha}^{-1}\right)\right] \mathrm{e}$, nas subparcelas, cinco modelos de pontas [leque simples (JSF11003), leque simples com indução de ar (ADIA11003), leque duplo com indução (AD-IA/D11003), leque simples martelinho com indução (TTI11003-VP) e cone vazio com indução (CV-IA10003)]. Os tratamentos foram aplicados em túnel de vento, à pressão de $300 \mathrm{kPa}$. Em analisador a laser, aplicando-se somente água, foram determinados, para todos os modelos de pontas, o diâmetro da mediana volumétrica, a amplitude relativa e a porcentagem de gotas com diâmetro inferior a $150 \mu \mathrm{m}$. As pontas hidráulicas CV-IA10003 e TTI11003-VP destacam-se por reduzir a deriva do herbicida 2,4-D e diminuir os danos a plantas de tomate. A adição do adjuvante LI-700 à calda de 2,4-D, independentemente do modelo de ponta, reduz a deriva desse herbicida e seus efeitos sobre a raiz de tomateiro. Entretanto, mesmo adotando-se essas tecnologias, a aplicação do herbicida 2,4-D próxima à cultura do tomate deve ser evitada.

PALAVRAS-CHAVE: Solanum lycopersicum; tecnologia de aplicação de herbicida; bicos de pulverização.

as 2,4-D, is even more harmful, because, even in low quantities, they may cause high losses in crops where plants are sensitive to their action mechanism (Egan et al. 2014).

The 2,4-D herbicide, an auxin agonist, is used worldwide in weed control, besides being an alternative to the use of glyphosate, in the case 
of dicotyledon weeds resistant or tolerant to this herbicide (Robinson et al. 2012, Craigmyle et al. 2013, Spaunhorst \& Bradley 2013). Moreover, the recent development and release of cultivars resistant to $2,4-\mathrm{D}$ will increase even more the use of this herbicide in rural properties (Mortensen et al. 2012) and, consequently, the possible problems with drift.

Among the crops susceptible to 2,4-D drifts, the vegetables stand out, as they are fundamental in food production. In addition to their strong social aspect, since the activities performed for cropping and harvesting demand a high quantity of labor, they are large job generators. Thus, the application of the 2,4-D herbicide next to crops like tomato must be minimally planned (Nascimento \& Mitsuo 2009). Therefore, when drift occurs, these plants may undergo changes in their metabolism, producing a disorganized cell growth and resulting in the abnormal growth of phloem vessels and adjacent tissues, thus generating plant epinasty (Souza et al. 2011).

To control the pesticides drift, there is in the market a wide range of alternatives for producers, such as hydraulic spray nozzles with venture system. These models produce drops of larger diameter than conventional nozzles without air induction, being less likely to be carried by the wind (Miller \& Ellis 2000). Hydraulic nozzles with air induction may be indicated for the application of herbicides in preemergence and/or systemic action, which require less weed coverage (Viana et al. 2007), as in the case of the 2,4-D herbicide.

Another tool available to control drift is the addition of adjuvants to the spray solution, in order to improve its physical and chemical properties, making it less sensitive to variations in ambient temperature, relative humidity and wind speed, during applications (Nascimento et al. 2012, Vilela \& Antuniassi 2013). However, the effect of the use of adjuvants in the solution varies in accordance with the hydraulic nozzle used (Cunha et al. 2010, Gandolfo et al. 2013, Mota \& Antuniassi 2013).

Some combinations of hydraulic nozzles with adjuvants mixed to the herbicide solution may be more effective in reducing the spray drift and, consequently, its damage in crops susceptible to the herbicide. Thus, this study aimed to evaluate the efficiency of different spray hydraulic nozzles with air induction, as well as the use of the LI-700 adjuvant, in the reduction of the 2,4-D herbicide drift, in tomato crop.

\section{MATERIAL AND METHODS}

The experiment was carried out in Rio Paranaíba (19¹3'0.90"S and 46 20'36.16”W), Minas Gerais state, Brazil, in 2017. In a wind tunnel (Figure 1), the drifts generated by each treatment were simulated according to a split-plot completely randomized design, with eight replications. In the plots, two herbicide solutions were used, with and without adjuvant: 2,4-D (670 $\left.\mathrm{g} \mathrm{ha}^{-1}\right)$ and 2,4-D $\left(670 \mathrm{~g} \mathrm{ha}^{-1}\right)+\mathrm{LI}-700\left(712.88 \mathrm{~g} \mathrm{ha}^{-1}\right)$. In the subplots, there were five hydraulic spray nozzle models: simple fan (JSF11003), simple fan with air induction (AD-IA11003), dual fan with air induction (AD-IA/ D11003), simple hammer fan with air induction (TTI11003-VP) and empty cone with air induction (CV-IA10003). An additional control without drift simulation was also evaluated. All treatments were applied in the wind tunnel, always under a working pressure of $300 \mathrm{kPa}$.

Before the drift evaluation, the drops spectrum was determined to the five nozzle models, with four replications, applying only water (ASAE 2009). The droplets spectrum was determined with the aid of a laser particle analyzer (Spraytech, Malvern Instruments Ltd., Malvern, Worcestershire, United Kingdom). The following variables were measured: volumetric median diameter (diameter of the drop that divides the volume of a population of droplets into two equal parts); relative amplitude of the drops population (SPAN); and percentage of the sprayed volume containing drops with a diameter of less than $150 \mu \mathrm{m}$, which indicates the potential risk of drifting during the application (Cunha et al. 2004). The focal distance was $750 \mathrm{~mm}$ and the device to count

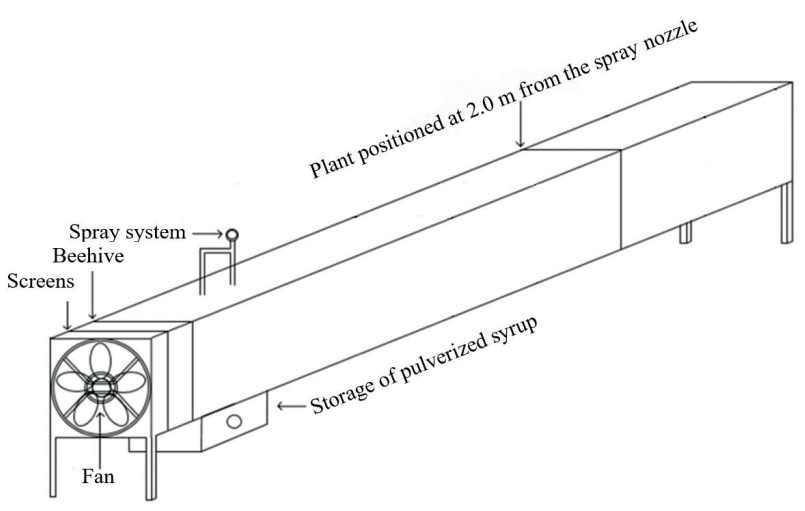

Figure 1. Wind tunnel used for the drift simulation ( $4.8 \mathrm{~m}$ length, $0.56 \mathrm{~m}$ width and $0.6 \mathrm{~m}$ height). 
the droplet size was adjusted to $0.10-2,500 \mu \mathrm{m}$. An electric motor was used to rotate the spraying bar, so that the entire jet that came out of the nozzle passed cross-sectionally, for three seconds, through the beam of light emitted by the laser scanner. Each hydraulic nozzle was positioned at $0.3 \mathrm{~m}$ from the device laser.

For the drift analysis, a wind chain in the tunnel was produced by three propeller fans driven by an electric motor with $200 \mathrm{~W}$ of power. Two screens (nylon mesh with $2 \mathrm{~mm}$ and metal mesh with $6 \mathrm{~mm}$ ) were positioned at $10 \mathrm{~cm}$ from the fan and, at $15 \mathrm{~cm}$ in front of the screens, a beehive was made with 560 metallic rectangles $(2 \mathrm{~cm}$ height, $3 \mathrm{~cm}$ width, $5 \mathrm{~cm}$ length and $0.2 \mathrm{~cm}$ thickness). The purpose of the screens and the beehive was to standardize and generate a laminar flow of air coming from the fan.

The active tense LI -700 adjuvant was used at a dose of $0.5 \mathrm{~L}$ for each $100 \mathrm{~L}$ of solution, while the 2,4-D (2,4-Dichlorophenoxyacetic acid) herbicide dose, trademark 2,4-D Norton, was $670 \mathrm{~g} \mathrm{ha}^{-1}$, i.e., simulating the application of $1.0 \mathrm{~L} \mathrm{ha}^{-1}$, for a solution volume of $200 \mathrm{~L} \mathrm{ha}^{-1}$. For the drift simulation of the solution sprayed inside the wind tunnel, tomato plants were used at the stage of five pairs of true leaves. Under greenhouse conditions, the plants were grown in $5.0 \mathrm{dm}^{3}$ pots filled with a Red-Yellow Latosol, fertilized according to the crop recommendations. Each pot was positioned at $2.0 \mathrm{~m}$ from the spray nozzle and, to produce an air flow, the fan was activated for 25 seconds, until the air flow was stabilized. Then, the spray system was turned on for one minute. After this time, the spray system and the fan were shut down for 25 seconds, and the pot was removed.

Each spray nozzle was positioned at $1.8 \mathrm{~m}$ from the fan, at the height of $0.5 \mathrm{~m}$, in relation to the tunnel floor. The spray system was formed by a piston pump (model BPF 22), with a flow rate of 14-22 $\mathrm{L} \mathrm{min}^{-1}$, and three pistons driven by a single phase electric motor induction, with power of $1.5 \mathrm{~kW}$. It was equipped with manual control and a glycerin gauge for adjustment and measurement of the working pressure. Before the evaluations, the gauge was calibrated using a test bench (model RB 500) equipped with a reference gauge for measurements. During the evaluations, the average temperature was $25^{\circ} \mathrm{C}$ and the relative humidity $54 \%$, conditions that were monitored with a thermo-hydro-portable digital anemometer (model Thal-300). The wind speed during the application was $2 \mathrm{~m} \mathrm{~s}^{-1}$, measured at the location where the spray nozzle was inserted into the tunnel.

The tomato plant evaluations were performed at 7, 14, 21 and 28 days after the spray drift simulation, by means of visual intoxication analysis, in relation to the control plants, in which there was no herbicide application. For this, a grade scale from $0 \%$ (no damage) to $100 \%$ (plant death) was used (SBCPD 1995). At 28 days, the plants were sectioned at the soil surface level for the dry mass quantification of shoots, and the substrate of the pots was removed and washed, extracting the roots for the root dry mass evaluation. For this, the samples were placed to dry in a forced air circulation oven at $65^{\circ} \mathrm{C}$, for $72 \mathrm{~h}$.

Homocedasticy and normality were verified by the Levene and Shapiro-Wilk tests, respectively. The variance analysis (Anova) was performed at a $5 \%$ significance and, when necessary, the treatment means were compared by the Tukey test, also at $5 \%$ of probability.

\section{RESULTS AND DISCUSSION}

For the evaluation of the hydraulic spray nozzles on the laser scanner, the Anova showed significant effects $(p<0.05)$ for all analyzed variables (Table 1). The hydraulic spray nozzles that generated

Table 1. Volumetric median diameter (VMD), percentage of solution volume containing drops with diameter less than $150 \mu \mathrm{m}$ (PRD) and relative amplitude of the drops population (SPAN) generated by five hydraulic spray nozzle models.

\begin{tabular}{lccc}
\hline \multicolumn{1}{c}{ Hydraulic nozzles } & VMD $(\mu \mathrm{m})$ & PRD (\%) & SPAN \\
\hline Simple fan (JSF11003) & $166.83 \mathrm{~d}^{1}$ & $43.39 \mathrm{e}$ & $1.78 \mathrm{~b}$ \\
Simple fan with air induction (AD-IA11003) & $483.15 \mathrm{~b}$ & $7.87 \mathrm{c}$ & $1.74 \mathrm{~b}$ \\
Simple hammer fan with air induction (TTI11003-VP) & $594.10 \mathrm{a}$ & $5.83 \mathrm{~b}$ & $2.08 \mathrm{c}$ \\
Dual fan with air induction (AD-IA/D11003) & $394.33 \mathrm{c}$ & $12.86 \mathrm{~d}$ & $1.73 \mathrm{~b}$ \\
Empty cone with air induction (CV-IA10003) & $545.00 \mathrm{a}$ & $3.10 \mathrm{a}$ & $1.44 \mathrm{a}$ \\
\hline $\mathrm{CV}(\%)$ & 5.27 & 6.55 & 4.09 \\
\hline
\end{tabular}

${ }^{1}$ Means followed by same letters do not differ by the Tukey test at $5 \%$ of probability. 
the highest averages to volumetric median diameter of drops were the TTI11003-VP and CV-IA10003, respectively the simple hammer fan with air induction and empty cone with air induction models. However, for the percentage of volume solution with drops lower than $150 \mu \mathrm{m}$ (PRD), CV-IA10003 provided the lowest $(3.10 \%)$ and TTI11003-VP the highest $(5.83 \%)$ potential drift risk. Due to the fact that these models show a similar volumetric diameter, it was expected that they also produced similar spray drift risks. However, the greater relative amplitude of the drops population (SPAN) of TTI11003-VP explains the fact that it showed the highest average to volumetric median diameter, but not the smallest one to PRD. Therefore, the higher the SPAN, the greater the variation in the drop diameters generated in the spraying (Madureira et al. 2015).

In contrast, the JSF 11003 spray nozzle produced the lowest average to volumetric median diameter $(166.83 \mu \mathrm{m})$, being 2.89 times lower than those for the hydraulic nozzles with air induction, and, consequently, presented a PRD 5.51 times higher (43.39\%). The higher the PRD and the lower the volumetric median diameter, the greater the risk of spray drift during application. Therefore, when the amount of drops with reduced diameter is increased $(<100 \mu \mathrm{m})$, there is a higher spray drift, due to the fact that such drops are more easily transported by the wind (Arvidsson et al. 2011).

Regarding the spray drift simulated in the wind tunnel on the tomato plants, the Anova for the percentage of intoxication showed a significant effect $(p<0.05)$ for the interaction between the kind of herbicide solution and the nozzle model used in the evaluations at 7 and 14 days after the spray drift simulation; and, at 21 and 28 days, no significant interaction $(p>0.05)$ was observed. In this case, there were significant differences $(\mathrm{p}<0.05)$ only among the nozzle models (Table 2).

In all the intoxication assessments, the JSF11003 nozzle generated the greatest damage. On the other hand, the hydraulic spray nozzles with air induction, mainly the models CV-IA10003 (empty cone) and TTI11003-VP (simple hammer fan), produced the lowest drift effects of 2,4-D on the plants (Table2), a fact which is also explained by the results in the drops spectrum of the hydraulic nozzles evaluated (Table 1).

During the evaluations, the damage differences caused among the hydraulic nozzles that use an air induction venture system were decreasing, due to the herbicide cumulative effect. But, even so, the AD-IA/D11003 nozzle (dual fan) generated a greater intoxication to the plants, in comparison with the other nozzles with air induction. These results are explained by the greater average to the percentage of drops lower than $150 \mu \mathrm{m}(\mathrm{PRD})$ and the lower average to the volumetric diameter of drops that such spray nozzle produces, in relation to other anti-drift nozzle models (Table 1).

The addition of the LI-700 adjuvant to the herbicide solution resulted in a significant reduction of plant intoxication, in the assessments at 7 and 14 days, but that happened only for JSF11003, the simple fan spray nozzle (Table 2). The high percentage of small drops produced by this hydraulic nozzle (Table 1) may explain this result, and the adjuvant may have reduced this value. However, this was not observed for the nozzles with air induction, because they already produce higher diameter drops. But these nozzles were more efficient in reducing the spray drift, in relation to the JSF11003, even in combination with the adjuvant.

Table 2. Intoxication (\%) in tomato plants at 7, 14, 21 and 28 days after the spray drift of the 2,4-D herbicide, with or without the LI-700 adjuvant, using five hydraulic spray nozzle models.

\begin{tabular}{clccccc}
\hline \multirow{2}{*}{ Days } & \multirow{2}{*}{ LI-700 } & \multicolumn{5}{c}{ Hydraulic nozzles $^{1,2}$} \\
\cline { 3 - 7 } & & JSF11003 & AD-IA11003 & AD-IA/D11003 & TTI11003-VP & CV-IA10003 \\
\hline \multirow{2}{*}{7} & Without & $54.63 \mathrm{Db}$ & $42.25 \mathrm{Ba}$ & $46.25 \mathrm{Ca}$ & $36.75 \mathrm{Aa}$ & $35.50 \mathrm{Aa}$ \\
& With & $50.75 \mathrm{Da}$ & $40.75 \mathrm{Ba}$ & $45.00 \mathrm{Ca}$ & $37.25 \mathrm{Aa}$ & $36.50 \mathrm{Aa}$ \\
\hline \multirow{2}{*}{14} & Without & $74.75 \mathrm{Db}$ & $62.25 \mathrm{Ba}$ & $66.25 \mathrm{Ca}$ & $56.75 \mathrm{Aa}$ & $55.50 \mathrm{Aa}$ \\
& With & $70.75 \mathrm{Da}$ & $60.75 \mathrm{Ba}$ & $65.00 \mathrm{Ca}$ & $57.25 \mathrm{Aa}$ & $56.50 \mathrm{Aa}$ \\
\hline \multirow{2}{*}{21} & NS & $81.44 \mathrm{C}$ & $72.81 \mathrm{AB}$ & $76.13 \mathrm{BC}$ & $71.38 \mathrm{AB}$ & $68.13 \mathrm{~A}$ \\
\hline 28 & NS & $96.88 \mathrm{~B}$ & $86.88 \mathrm{~A}$ & $92.81 \mathrm{AB}$ & $88.75 \mathrm{~A}$ & $89.69 \mathrm{~A}$ \\
\hline
\end{tabular}

${ }^{1}$ JSF11003: simple fan; AD-IA11003: simple fan with air induction; AD-IA/D11003: dual fan with air induction; TTI11003-VP: simple hammer fan with air induction; CV-IA10003: empty cone with air induction. ${ }^{2}$ Means followed by the same uppercase letters in the rows and lowercase letters in the columns, for each day, do not differ among themselves by the Tukey test at $5 \%$ of probability. NS: contrast "without $v$. with adjuvant" not significant at $5 \%$ of probability. 
Table 3. Shoot and roots dry mass of tomato plants after the spray drift of the herbicide 2,4-D, with or without the LI-700 adjuvant, using five hydraulic spray nozzle models.

\begin{tabular}{|c|c|c|c|c|c|c|c|}
\hline \multirow{2}{*}{ Dry mass (g) } & \multicolumn{5}{|c|}{ Hydraulic nozzles ${ }^{1,2}$} & \multirow{2}{*}{ Control } & \multirow{2}{*}{$\mathrm{CV}(\%)$} \\
\hline & JSF 11003 & AD-IA 11003 & AD-IA/D 11003 & TTI 11003-VP & CV-IA 10003 & & \\
\hline Shoot & $9.31 \mathrm{c}$ & $13.37 \mathrm{~b}$ & $9.17 \mathrm{c}$ & $15.49 \mathrm{~b}$ & $14.24 \mathrm{~b}$ & $24.00 \mathrm{a}$ & 13.76 \\
\hline Root & $0.92 \mathrm{~d}$ & $1.15 \mathrm{~cd}$ & $0.94 \mathrm{~d}$ & $1.81 \mathrm{bc}$ & $2.06 \mathrm{~b}$ & $8.39 \mathrm{a}$ & 17.42 \\
\hline \multirow{2}{*}{ Dry mass (g) } & \multicolumn{5}{|c|}{ LI-700² } & \multirow{2}{*}{ Control } & \multirow{2}{*}{$\mathrm{CV}(\%)$} \\
\hline & & Without & & With & & & \\
\hline Root & & $2.34 \mathrm{c}$ & & $2.75 \mathrm{~b}$ & & $8.39 \mathrm{a}$ & 21.48 \\
\hline
\end{tabular}

${ }^{1}$ JSF11003: simple fan; AD-IA11003: simple fan with air induction; AD-IA/D11003: dual fan with air induction; TTI11003-VP: simple hammer fan with air induction; CV-IA10003: empty cone with air induction. ${ }^{2}$ Means followed by the same letters in the rows do not differ among themselves by the Tukey test at $5 \%$ of probability.

For the analyses of shoot and roots dry mass of tomato plants, there was no interaction between the herbicide solution and the nozzle models used. However, the hydraulic nozzles generated significant differences $(p<0.05)$, both in the shoot and roots dry mass (Table 3 ). The plants under spray drift simulation with the models CV-IA10003, TTI11003-VP and AD-IA11003 produced the greater means to shoot dry mass, which were inferior only to the average observed for the control treatment. These results are attributed to the smaller percentage of small drops (PRD) produced by these models (Table 1).

For the evaluation of root dry mass, the CV-IA10003 and TTI11003-VP nozzles had the best performance, reducing the spray drift effects of $2,4-\mathrm{D}$ in the plants (Table 3 ). Thus, these hydraulic nozzles proved to be more efficient in reducing the generated drift, due to the transport of reduced diameter drops by the wind. Therefore, these nozzle models generated the greatest averages to volumetric median diameter and the smallest ones to PRD (Table 1), and, consequently, fewer herbicide damages in the plants.

On the other hand, the addition of the LI-700 adjuvant produced significant results only for the evaluation of root dry mass (Table 3 ). In this case, the plants under the spray drift simulation of 2,4-D with a LI700 solution had a plus of $17.52 \%$ in the dry root mass, in relation to those without the adjuvant. This indicates that the addition of the LI-700 adjuvant to the spraying solution reduced the drift of the 2,4-D herbicide.

The choice of the appropriate spray nozzle may reduce the tomato root intoxication in $13.6 \%$, while, with the addition of the LI-700 adjuvant, the reduction does not exceed $4.9 \%$. However, under the conditions of this study, none of the spray nozzle models evaluated, with or without the adjuvant, was effective in reducing the 2,4-D drift to the point of avoiding the plants death.

\section{CONCLUSIONS}

The hydraulic nozzles CV-IA10003 (empty cone) and TTI11003-VP (simple hammer fan) outstand by reducing the 2,4-D herbicide spray drift and decreasing the damage to tomato plants. The addition of the LI-700 adjuvant to the 2,4-D syrup, independently of the hydraulic nozzle model, reduces the drift of this herbicide and its effects on the tomato root. However, even adopting these technologies, the application of the 2,4-D herbicide close to tomato crops should be avoided.

\section{ACKNOWLEDGMENTS}

To the Coordenação de Aperfeiçoamento de Pessoal de Nível Superior (Capes), for the financial support and fellowship grant.

\section{REFERENCES}

AMERICAN SOCIETY OF AGRICULTURAL ENGINEERS (ASAE). Spray nozzle classification by droplet spectra: ASAE S572.1. St. Joseph: ASAE, 2009.

ARVIDSSON, T.; BERGSTRÖM, L.; KREUGER, J. Spray drift as influenced by meteorological and technical factors. Pest Management Science, v. 67, n. 5, p. 586-598, 2011.

CRAIGMYLE, B. D.; ELLIS, J. M.; BRADLEY, K. W. Influence of herbicide programs on weed management in soybean with resistance to glufosinate and 2,4-D. Weed Technology, v. 27, n. 1, p. 78-84, 2013.

CUNHA, J. P. A. R.; BUENO, M. R.; FERREIRA, M. C. Espectro de gotas de pontas de pulverização com adjuvantes de uso agrícola. Planta Daninha, v. 28, n. special, p. 1153-1158, 2010.

CUNHA, J. P. A. R. et al. Espectro de gotas de bicos de pulverização hidráulicos de jato plano e de jato cônico 
vazio. Pesquisa Agropecuária Brasileira, v. 39, n. 10, p. 977-985, 2004.

EGAN, J. F.; BARLOW, K. M.; MORTENSEN, D. A. A meta-analysis on the effects of 2,4-D and dicamba drift on soybean and cotton. Weed Science, v. 62, n. 1, p. 193206, 2014.

GANDOLFO, M. A. et al. Influência de pontas de pulverização e adjuvantes na deriva em caldas. Revista Ciência Agronômica, v. 44, n. 3, p. 474-480, 2013.

MADUREIRA, R. P.; RAETANO, C. G.; CAVALIERI, J. D. Interação pontas-adjuvantes na estimativa do risco potencial de deriva de pulverizações. Revista Brasileira de Engenharia Agrícola e Ambiental, v. 19, n. 2, p. 180-185, 2015.

MILLER, P. C. H.; ELLIS, M. C. B. Effects of formulation on spray nozzle performance for applications from groundbased boom sprayers. Crop Protection, v. 19, n. 8-10, p. $609-615,2000$.

MORTENSEN, D. A. et al. Navigating a critical juncture for sustainable weed management. BioScience, v. 62, n. 1, p. $75-85,2012$.

MOTA, A. A. B.; ANTUNIASSI, U. R. Influência de adjuvantes no espectro de gotas de ponta com indução de ar. Energia na Agricultura, v. 28, n. 1, p. 1-5, 2013.

NASCIMENTO, A. et al. Deposição de glifosato e utilização de adjuvante para diferentes pontas de pulverização e horário de aplicação. Applied Research \& Agrotechnology, v. 5, n. 2, p. 105-116, 2012.
ROBINSON, A. P.; SIMPSON, D. M.; JOHNSON, W. G. Summer annual weed control with 2,4-D and glyphosate. Weed Technology, v. 26, n. 4, p. 657-660, 2012.

NASCIMENTO, E. R. do; MITSUO, Y.O. Desenvolvimento inicial de olerícolas cultivadas em solos contaminados com resíduos de 2,4-D + picloram. Semina, v. 30, n. 1, p. 47-54, 2009.

SOCIEDADE BRASILEIRA DA CIÊNCIA DAS PLANTAS DANINHAS (SBCPD). Procedimentos para instalação, avaliação e análise de experimentos com herbicidas. Londrina: SBCPD, 1995.

SOUZA, L. A.; CUNHA, J. P. A. R.; PAVANIN, L. A. Eficácia e perda do herbicida 2,4-D amina aplicado com diferentes volumes de calda e pontas de pulverização. Planta Daninha, v. 29, n. special, p. 11491156, 2011.

SPAUNHORST, D. J.; BRADLEY, K. W. Influence of dicamba and dicamba plus glyphosate combinations on the control of glyphosate-resistant waterhemp (Amaranthus rudis). Weed Technology, v. 27, n. 4, p. 675-678, 2013.

VIANA, R. G. et al. Características técnicas de pontas de pulverização LA-1JC e SR-1. Planta Daninha, v. 25, n. 1, p. 211-218, 2007.

VILELA, C. M.; ANTUNIASSI, U. R. Evaporação de gotas de caldas contendo fungicidas e adjuvantes depositadas em superfície. Engenharia Agrícola, v. 28, n. 2 , p. $65-73,2013$. 